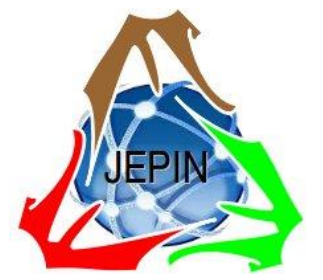

\title{
Mobile expert for Tobacco Disease Identification Using The Fuzzy Inference System Tsukamoto
}

\author{
Mohammad Syarief ${ }^{\# 1}$, Imamah $^{\# 2}$, Husni ${ }^{\# 3}$, Akhmad Tajuddin Tholaby MS ${ }^{\# 4}$ \\ \#Jurusan Teknik Informatika, Fakultas Teknik, Universitas Trunojoyo Madura \\ Bangkalan, Jawa Timur, Indonesia \\ ${ }^{1}$ mohammad.syariefetrunojoyo.ac.id \\ 2i2metrunujoyo.ac.id \\ 3i2metrunujoyo.ac.id \\ 4i2metrunujoyo.ac.id
}

\begin{abstract}
Madura Island is a producer of aromatics tobacco known as Madura Tobacco. One type of Madura tobacco that has superior quality is tobacco Campalok. This tobacco is only in the village of Bakeong Guluk-Guluk district of Sumenep. Its price for each kilogram can penetrate up to two million rupiahs. But failing to harvest due to illness or pests can decrease the quality and price of tobacco Campalok, while the access to consult the agricultural experts in Sumenep district is far enough so the public difficulty getting information faster on tobacco disease treatment. This is the underlying research on the expert system for the identification of diseases in the Android-based tobacco crop. This Expert System was developed by utilizing Android-based mobile technology using the Fuzzy Inference System Tsukamoto method. Farmers who will use this application only enter the characteristics of tobacco leaves that are exposed to pests then the expert system will provide a way of overcoming the pest disease based on the expertise of agricultural experts in Sumenep district Using the Fuzzy method. The result of this research showed that 8 from 10 of diseases were successfully detected by the application so that the accuracy of this application compared to the human expert system is $80 \%$.
\end{abstract}

Keyword - Disease, expert system, Fuzzy Inference System Tsukamoto Method, Quality, Tobacco.

\section{INTRODUCTION}

Tobacco is a unique cultivation plant that has been utilized hundreds of years ago. The management of tobacco into a product that can be utilized, must go through a variety of complex and long processes. Besides, knowledge, experience, skills, persistence, and thoroughness in management are needed[1].

East Java is one of the main tobacco-producing areas in Indonesia. Based on the data from the Jatim Plantation office, every year East Java contributes to the production of tobacco of 83,404 tonnes or about $50-55 \%$ of national demand. The cultivation of tobacco in East Java spread in 20 districts with an average area of 110,791 hectares consisting of tobacco voor-Oogst of 103,878 hectares and $\mathrm{Na-Oogst}$ amounting to 6,913 hectares [2].
Madura is one of the producers of tobacco located in East Java. Madura Island has four regencies namely Bangkalan, Sampang, Pamekasan and Sumenep. Tobacco is a compound of agriculture in the four districts, but the best tobacco trees are grown mainly in the district of Sumenep. There are three districts in Sumenep which are Best tobacco producers in Madura, namely Prancak, Montorna and Bakeong villages. Of the three villages, the best quality of tobacco is in the Jambangan, Bakeong village known as the tobacco name Campalok. The term Campalok is derived from the name of the location of the land located around the cemetery with a tree named Campalok. The name is then pinned to the tobacco produced in this village.

But as with other crops, pests and diseases became the main enemy for tobacco farmers in Campalok. Pests are all kinds of animals or animals that damage plants and harm people in terms of the economy[3]. While the disease on tobacco can be caused by viruses and fungi. Based on interviews conducted by farmers when discovering pests and diseases that attack their tobacco is to pluck crops in hopes of not being transmitted to others without thinking about aspects of pest control in other ways. What should be done by the farmers is to consult the agricultural experts in Sumenep district, but this is not done due to the distance.

Distance from the city of Sumenep to the village Bakeong about an hour with a mileage of 55 kilometers. This far enough distance, causing access for a consultation to the Agriculture Service district of Sumenep is not easy and tends to be rarely done by society for many reasons. One of the reasons they think becomes a barrier is the cost of transportation and travel time to the agricultural service. Distance reasons make the importance of the consultation override. However, the agricultural service will be very helpful to the population in preventing pests that infect their tobacco[4].

This problem is an obligation of researchers in the University of Trunojoyo Madura, to solve with the 
implementation of information technology through an expert system. The Expert system is the process of adoption of human knowledge to a computer with the aim of computers that can have human expertise and solve problems like an expert[5][6][7]. The way that can be done to bring the distance closer is to present the expertise of agriculture experts in the district office of Sumenep in the hands of Bakeong village farmers in particular in the form of Android-based applications. This mobile application is developed based on android, for ease of use, and can be used by farmers in making the diagnosis by themselves without meeting the experts[8][9]. The expert system moves the expertise of agricultural experts using the fuzzy method, farmers simply enter the symptoms of disease in tobacco plants then the system will draw based on symptoms and produced the output of diagnosis and ways to prevent. In this research, we use a fuzzy approach as one way to model underlying ambiguity and uncertainty, in particular related to the subjective statements[10].

\section{RESEARCH METHODS}

The stages in this study include several processes shown in figure 1. Detailed explanations of the stages of the study are explained below:

\section{A. Study Literature}

At this stage is the collected theory related to the research on the disease in tobacco and the Fuzzy method.

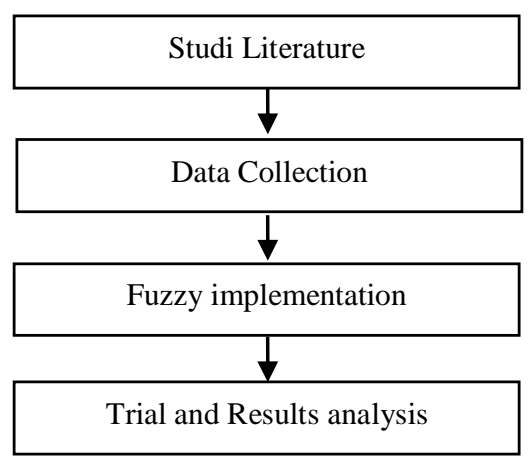

Figure 1. Research methods

a. Diseases and pests in tobacco

Knowledge representation and knowledge engineering are central to AI research[11]. Knowledge Base is required in an expert system as a reference for diagnosing to be done. There are several pests and diseases on tobacco including the following:

\section{Insects}

The symptoms shown as a result of the Insects are the irregular and white-colored holes on bite scars. Besides, the leaves are perforated and long run out. The leaves become lined, yellow and wither. There are black dots of puncture in the leaves.

2. Virus Infection

The symptoms shown as a result of disease or viral attack are as follows, the leaves are punctate with green to yellow color. The leaves are lined up to appear curly. Leaves narrow and plants become runt. Examples of viruses are tobacco mosaic virus (TMV) and cucumber mosaic virus (CMV)[12].

3. Fungus Infection

The fungal attack will cause many symptoms, for example, is a plant whose leaves are still green suddenly hang wilted and finally die, the base of the stem near the rotten soil surface is brown.

b. Fuzzy Inference Tsukamoto

The process of diagnoses with a Fuzzy Inference System Tsukamoto through several stages is the first one we do fuzzification the input value is converted into membership degrees using the Membership function graph[13]

The Membership function $\left(\mu_{\mathrm{f}}=\right.$ membership function) is a curve indicating the mapping between the data input points into its membership value (membership degree).

Take $U$ as the universe from the set of objects $\{U\}$. Fuzzy set of $\mathrm{F}$ in the U-universe is expressed in the membership value $\mu_{\mathrm{F}}$ which has interval value. The fuzzy set is usually expressed by: $[0,1]$

$$
F=\left\{\left(u, \mu_{f}(u)\right) \mid u \varepsilon U\right\}
$$

If $\mathrm{U}$ continue then the set of $\mathrm{F}$ can be written with:

$$
F=\int \mu_{f}(u) / u
$$

If $\mathrm{U}$ discrete then the set of $\mathrm{F}$ can be written with:

$$
F=\sum \mu_{f}\left(u_{i}\right) / u_{i}
$$

The second process is calculating the value of the membership degree () of the symptoms entered.

\section{Fuzzification}

The fuzzification process is a process for converting a non-fuzzy variable (variable numeric) to a fuzzy variable (variable linguistic)[8]. The values of inputs that have been quantized before being processed by the fuzzy logic handler must be changed first into the fuzzy variable. Through the membership function that has been compiled, from the input values to the fuzzy information that is useful later for the process of processing in a fuzzy anyway. In other words, fuzzification is a numeric mapping (crisp point)[14]

\section{The Fuzzy Rule Base}

The fuzzy rule base is expressed in the form of ' IF-THEN ' which is the essence of the fuzzy relationship, expressed with R, also called the fuzzy implications in the basic knowledge can be defined as a set of phase fuzzy implications. The basic rule of fuzzy is in common form:

$\mathrm{R}: \mathrm{IFx}_{1}$ is $\mathrm{F}_{1}{ }^{1} \mathrm{AND} \ldots \mathrm{AND} \ldots \mathrm{X}_{\mathrm{n}}$ is $\mathrm{F}_{\mathrm{n}}{ }^{1}$, THEN $\mathrm{y}$ is $\mathrm{G}^{1}$ 
Where $F_{1}{ }^{1}$ and $G^{1}$ are the FUZZY sets of Each $I n U_{i} \subset R$ and $\mathrm{VR}$, and $\mathrm{YV}$ is a variable linguistic. $\subset \underset{-}{x}=\left(x^{1}, \ldots ., x^{n}\right)^{T} \in U_{1} X \ldots . X U_{n} \in$

\section{Inference System}

In fuzzy logic reasoning, there are two main types of decision making namely generalized modus ponens (GMP) and generalized Tollens (GMT) mode.

Generalized Modus Ponens (GMP)

Statement 1 (rule): if $x A$ then $y$ is $B$

Statement 2 (FACT): $x$ is $A^{\prime}$

Resolution: $y$ is $B^{\prime}$

Completion B ' can be calculated B ' $=A^{~}{ }^{\circ} \mathrm{R}$ where $\mathrm{R}$ is the fuzzy relationship of the implications of ' if $A$ then $B$ ', the ${ }^{\circ}$ Mark is the composition operator, and a ' is a fuzzy set that has a form; A, very $\mathrm{A}$, more or less $\mathrm{A}$, not $\mathrm{A}$ and so on.

General Modus Tollens (GMT)

Statement 1 (rule): if $x A$ then $y$ is $B$

Statement 2 (FACT): $x$ is $B^{\prime}$

Resolution: $y$ is $A^{\prime}$

Completion $\mathrm{B}^{\prime}$ can be narrated $\mathrm{A}^{\prime}=\mathrm{R}^{\circ} \mathrm{B}$ '.

\section{Defuzzification}

The defuzzification process is a process of changing the decision of the reasoning process that is still in the fuzzy form, i.e. the output membership degree to be changed back into a nonfuzzy variable numeric[15]. Two commonly used methods of defuzzification:

\section{Maximum of Mean (MOM)}

This method is defined as:

$$
\begin{array}{ll}
v_{O} & =\sum_{j=1}^{j} \frac{v_{j}}{J} \\
\mathrm{~V}_{\mathrm{o}} & =\text { output value. } \\
\mathrm{J} & =\text { Maximum Price amount. } \\
\mathrm{V}_{\mathrm{J}} & =\text { maximum output value to-J. }
\end{array}
$$

$\mu_{\mathrm{V}}(\mathrm{v})=$ Degree of membership element-element on the fuzzy set $\mathrm{v}$.

$$
\mathrm{V}=\text { Universe talks. }
$$

Center of Area (COA)

This method is as follows:

$$
v_{o}=\frac{\sum_{k=1}^{m} v_{k} \mu_{k}\left(y_{k}\right)}{\sum_{k=1}^{m} \mu_{v}\left(y_{k}\right)}
$$

$$
\begin{array}{ll}
\mathrm{V}_{\mathrm{o}} & =\text { output value. } \\
\mathrm{m} & =\text { quantization rate. } \\
\mathrm{V}_{\mathrm{k}} & =\mathrm{k} \text { element. }
\end{array}
$$

$\mu_{\mathrm{v}}(\mathrm{v})=$ Degree of membership element-element on the fuzzy set $v$.

$$
\mathrm{V}=\text { Universe talks. }
$$

The third process is to enter the value of membership degrees in the rule base or base of rules that have been created based on expert opinion, and the last process is the process of defuzzification[15]. From defuzzification, results can be concluded in the form of disease diagnosis solutions.

\section{B. Data Collection}

The conclusion in the study was obtained by linking the facts and knowledge about tobacco disease that has been modeled in rules-based. Facts and knowledge will be translated by the creator of the system to be knowledge-

\begin{tabular}{|c|c|c|}
\hline $\begin{array}{l}\text { Sympthoms } \\
\text { Code }\end{array}$ & Symptoms (G) & Weighted \\
\hline G1. & $\begin{array}{l}\text { The leaves holes irregular and } \\
\text { white on bite-used wounds }\end{array}$ & 3 \\
\hline G2 & $\begin{array}{l}\text { The leaves are holes and long run } \\
\text { out }\end{array}$ & 5 \\
\hline G3 & $\begin{array}{l}\text { Leaves become lined, yellow, and } \\
\text { wither }\end{array}$ & 8 \\
\hline G4 & Stem seedlings broken & 15 \\
\hline G5 & $\begin{array}{l}\text { Plants become fallen and wither } \\
\text { because the base of the stem is cut. }\end{array}$ & 14 \\
\hline G6 & $\begin{array}{l}\text { The points of the scar are blackish } \\
\text { or silvery. }\end{array}$ & 8 \\
\hline G7 & Yellow leaf & 10 \\
\hline G8 & Plants become dwarfs & 12 \\
\hline G9 & Crops wither and eventually die & 13 \\
\hline G10 & $\begin{array}{l}\text { Striped leaves with green to } \\
\text { yellow color }\end{array}$ & 8 \\
\hline G11 & Leaves wrinkle-looking curly & 8 \\
\hline G12 & Dried leaves & 4 \\
\hline G13 & Narrow leaves & 6 \\
\hline G14 & $\begin{array}{l}\text { Brownish-spotting (concentric) } \\
\text { leaves }\end{array}$ & 9 \\
\hline G15 & $\begin{array}{l}\text { The leaves of the round patches } \\
\text { are white to the yellow leaf and } \\
\text { then brown. }\end{array}$ & 9 \\
\hline G17 & Brown stem Base as scorched & 5 \\
\hline G18 & $\begin{array}{l}\text { Pith rod dries, crumpled and } \\
\text { shrinkage. }\end{array}$ & 6 \\
\hline G19 & $\begin{array}{l}\text { Roots covered in white } \\
\text { mushrooms. }\end{array}$ & 14 \\
\hline G20 & $\begin{array}{l}\text { Plant stem if it is torn in the white } \\
\text { slime of milk. }\end{array}$ & 13 \\
\hline G21 & $\begin{array}{l}\text { The roots become rotten Brown to } \\
\text { black. }\end{array}$ & 16 \\
\hline
\end{tabular}
based stored in the database and will be used by the system in the process of the diagnosis conclusion. The knowledge base used in this study covers the types of diseases, symptoms of diseases and relationships between the symptoms and diseases of Tobacco. In more detail, the type of tobacco disease obtained as a knowledge base in this research is shown in table 1 .

TABLE I

SYMPTOMS OF TOBACCO 
A weighted on table 1 was obtained from consultation to agricultural experts in the district of Sumenep. Weights are obtained by comparing each parameter relative to other parameters based on their importance. The purpose of the weighted one is to establish the symptoms that have the highest priority in the examination.

Meanwhile, the correlation between the disease and symptoms is shown in table 2 .

TABLE II

SYMPTOMS AND DISEASES OF TOBACCO

\begin{tabular}{|c|l|l|}
\hline NO & Cause & \multicolumn{1}{|c|}{ Symptoms } \\
\hline 1 & Insects & G1,G2,G3,G4,G5,G6 \\
\hline 2 & Virus & G3,G7,G8,G9,G11 \\
\hline 3 & Fungi & $\begin{array}{l}\text { G10,G12,G13,G14,G15,G16,G17,G18, } \\
\text { G19,G20 }\end{array}$ \\
\hline 4 & Bacteria & G10,G11,G12,G13,G15,G16,G20,21 \\
\hline
\end{tabular}

C. Identification Disease and Pest using Fuzzy methods

In this research, the user who will do the diagnosis is asked to choose the symptoms then answer YES, NOT or GREATLY according to the appearance of the symptoms. For example, farmers find holes in the leaves, if the hole looks very much then the answer is GREATLY, but if the number of holes leaves a little, then quite answered YES or NOT if not found holes in the leaves. This weighted process follows the table 3. Using the Fuzzy method, it can be simulated if the user gives wrong or correct answers on symptoms, then its calculation process as seen in table 3 .

TABLE III

RULE INPUT USER

\begin{tabular}{|l|l|}
\hline User Input & Weighted \\
\hline No & 0 \\
\hline Yes & 0.8 \\
\hline Greatly & 1 \\
\hline
\end{tabular}

\section{Trial and Results analysis}

The test is done by doing a diagnose using an application and compared with the diagnose of human experts. Human expert is a farming expert in the district office of Sumenep, and in this research, there are two agricultural experts used as a referral for application testing.

\section{RESULTS AND DISCUSSION}

Expert system application development using mobile phones has been successfully implemented in the Android operating system. The user interface including the main user interface, input symptoms interface, and the diagnosis and actions of prevention and treatment are illustrated in Figure 1.

In this system, the user should choose a diagnosis menu, then the system will ask questions according to the symptoms in table 2 . If the user sets true for the first symptoms question as shown in table 2, then the system will lead the user to the next question. If the user sets not true for the second symptoms question then the system will be directed to the other question until the system finds a result or prove symptoms adjusted to rule-based. The final results of the diagnosis will be displayed in figure 1 .

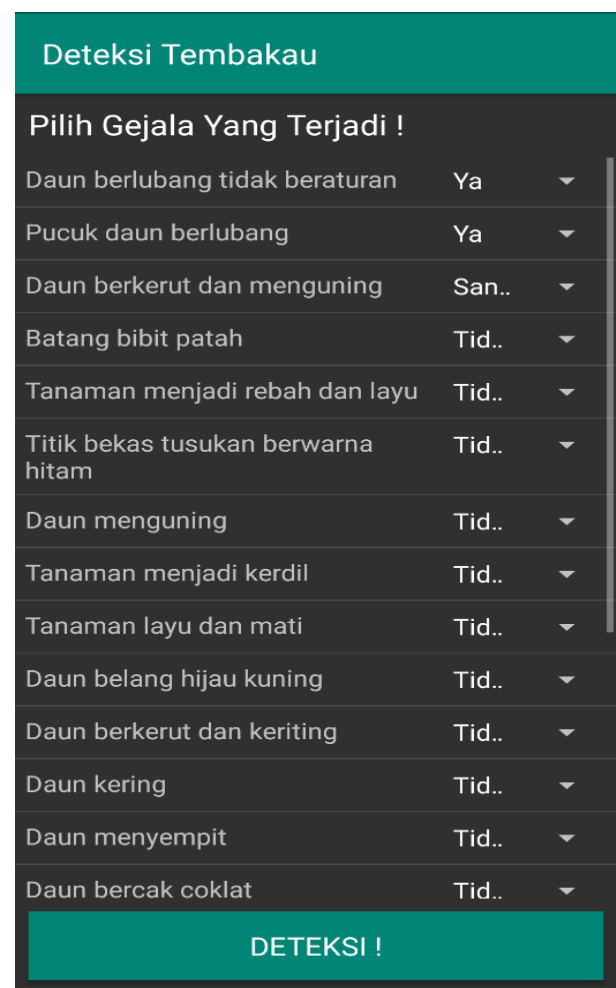

Figure 1. User Interface for Mobile Expert system

\section{Deteksi Tembakau}

\section{Hasil Deteksi}

\section{Insekta}

Gejala yang sama : 3

\section{Virus}

Gejala yang sama : 1

Figure 2. Results of disease diagnosis in tobacco 


\section{B. Accuracy Testing}

This mobile expert system must go through feasibility test before its used by farmers. This test is done by comparing the results of the diagnosis by a mobile expert system Compared to the results of human experts. In table 4 , it is shown tests based on the symptoms experienced by 10 users, along with the answers included in the mobile expert. For example, in the first Test, Users find that The leaves holes irregular and white on bite-used wounds, so the answer for G1 is YES, and the users also find that there are many points of the scar that are blackish or silvery, so the answer for G6 is GREATLY.

TABLE IV

TRIAL TO TEST ACCURACY

\begin{tabular}{|l|l|l|}
\hline No & Symptoms Codes & $\begin{array}{l}\text { Answers G=Yes, } \\
\text { G=Greatly) }\end{array}$ \\
\hline 1 & G1,G6 & Y, G \\
\hline 2 & G10,G19 & Y,Y \\
\hline 3 & G1,G11,G16,G21 & Y,G,Y,G \\
\hline 4 & G11,G15,G18 & Y,Y,G \\
\hline 5 & G10,G15,G20,G21 & G,G,Y,Y \\
\hline 6 & G8,G11,G15,G17 & Y,G,Y,Y \\
\hline 7 & G17,G19, G20 & Y,G,G \\
\hline 8 & G10,G16,G17 & G,Y,Y \\
\hline 9 & G11,G18 & Y,Y \\
\hline 10. & G1,G11,G16, G17 & G,G,Y,Y \\
\hline
\end{tabular}

TABLE $\mathrm{V}$

THE COMPARISON RESULTS OF HUMAN EXPERT AND EXPERT SYSTEMS

\begin{tabular}{|c|c|c|c|c|}
\hline $\begin{array}{l}\text { No } \\
\cdot\end{array}$ & $\begin{array}{l}\text { Mobile } \\
\text { Expert }\end{array}$ & $\begin{array}{c}\text { Prosentation } \\
\text { of diagnosis } \\
\text { Results }(\%)\end{array}$ & $\begin{array}{c}\text { Human } \\
\text { expert }\end{array}$ & $\begin{array}{c}\text { Accuracy } \\
\text { results }\end{array}$ \\
\hline 1 & Insects & 11.07 & Insects & Verified \\
\hline 2 & $\begin{array}{l}\text { Mushrooms } \\
\text { Bacteria }\end{array}$ & $\begin{array}{l}65.61 \\
11.81 \\
\end{array}$ & Mushrooms & Verified \\
\hline 3 & $\begin{array}{l}\text { Mushrooms } \\
\text { Bacteria } \\
\text { Insects } \\
\text { Virus }\end{array}$ & $\begin{array}{l}41,64 \\
27,76 \\
13,88 \\
13,88 \\
\end{array}$ & Mushrooms & Verified \\
\hline 4 & $\begin{array}{l}\text { Mushrooms } \\
\text { Bacteria } \\
\text { Virus }\end{array}$ & $\begin{array}{l}45,45 \\
45,45 \\
22,73\end{array}$ & Mushrooms & Verified \\
\hline 5 & $\begin{array}{l}\text { Mushrooms } \\
\text { Bacteria }\end{array}$ & $\begin{array}{l}60,51 \\
15,13\end{array}$ & Mushrooms & Verified \\
\hline 6 & $\begin{array}{l}\text { Virus } \\
\text { Mushrooms } \\
\text { Bacteria }\end{array}$ & $\begin{array}{l}26,20 \\
26,20 \\
26,20\end{array}$ & $\begin{array}{l}\text { Virus and } \\
\text { Bacteria }\end{array}$ & Failed \\
\hline 7 & $\begin{array}{l}\text { Mushrooms } \\
\text { Bacteria }\end{array}$ & $\begin{array}{l}60,42 \\
20,14\end{array}$ & Mushrooms & Verified \\
\hline 8 & $\begin{array}{l}\text { Mushrooms } \\
\text { Bacteria }\end{array}$ & $\begin{array}{l}39,73 \\
26,49\end{array}$ & Mushrooms & Verified \\
\hline 9 & $\begin{array}{l}\text { Virus } \\
\text { Mushrooms } \\
\text { Bacteria }\end{array}$ & $\begin{array}{l}31,25 \\
31,25 \\
31,25\end{array}$ & Virus & Verified \\
\hline 10 & $\begin{array}{l}\text { Mushrooms } \\
\text { Bacteria } \\
\text { Insects } \\
\text { Virus }\end{array}$ & $\begin{array}{c}19.01 \\
19,01 \\
9,50 \\
9,50\end{array}$ & Bacteria & Failed \\
\hline
\end{tabular}

Based on the test results that have been done using the user's answer criteria in table 4, the results of accuracy assessment can be obtained as seen in table 5 . We have 10 experiments that have been conducted, involving 10 tobacco farmers, obtained the results that there are two symptoms failed to be diagnosed using the mobile expert system, diagnose failure was obtained in the sixth and tenth tests.

This diagnose error is caused by a sorting error at the same probability value. Notice on the sixth Test, human experts distort the symptoms of G8, G11, G15, G17 as diseases caused by viruses and bacteria, whereas the results diagnose mobile experts are viruses, fungi, and bacteria with the value of each trust Worth 26.20. From here it can be known that the cause of failure of detection because of the fault only. The same is the case with the tenth Test, diagnose human experts over the symptoms with the code G1, G11, G16, G17 is bacteria, while the diagnose result of the mobile expert is fungi and bacteria with a trust rate of 19.20. If observed can be concluded that diagnose error occurs due to confusion of the process of determination of ranking.

Based on 10 tests that have been conducted, 8 diseases can be detected by the mobile expert system and 2 failed diseases detected. Based on this result, accuracy results are calculated as follows:

$$
\begin{aligned}
& \text { Accuracy }=(\mathrm{MES} / \mathrm{HE}) \times 100 \% \ldots \ldots \ldots . . .1 \\
& \text { Accuracy }=(8 / 10) \times 100 \%=77 \%
\end{aligned}
$$

Based on this test, accuracy MES using the Fuzzy Inference System Tsukamoto method is $80 \%$.

\section{CONCLUSION}

This research suggests Fuzzy Inference System Tsukamoto to detect diseases and symptoms of tobacco. There are 21 symptoms used in determining four types of disease in tobacco. The result of this research showed that 8 from 10 of diseases were successfully detected by the application so that the accuracy of this application compared to the human expert system is $80 \%$.

The application failed to detect two diseases on this research caused by there is a common value in the detection result, causing a sequence of the alignment that is not appropriate with the results of a human expert. So in future research, we can combine Fuzzy with another method to solve the problem of how to perform the alignment accuracy if there is equal value in the detection result using FIS Tsukamoto.

\section{ACKNOWLEDGMENT}

We thanks to the Engineering Faculty, The University of Trunojoyo Madura, which has funded this research through research programs for lecturers. 


\section{REFERENCES}

[1] T. B. Mukhlisoh, Nanik Anita; Wibowo, Nugroho Setyo; Irawan, "Penerapan Metode Forward Chaining dalam Sistem

Pakar untuk menentukan Diagnosa Hama dan Penyakit

E. S. Hani, "Pemodelan dan Strategi Competitiveness

Agribisnis Tembakau Besuki NaOogst di Jawa Timur.," $J$ -

SEP, 59-69, pp. 59-69, 2009.

[3] F. S. Nugraha, F. H. Purwanto, and M. Huda, "Analisis

Perancangan Arsitektur Sistem Pakar Penyakit Padi di Sleman Yogyakarta," Voice Of Informatics, vol. 6, no. 2, pp. 1-12,

2017

[4] M. Arifin, S. Slamin, and W. E. Y. Retnani, "Penerapan Metode Certainty Factor Untuk Sistem Pakar Diagnosis Hama Dan Penyakit Pada Tanaman Tembakau," Berk. Sainstek, vol. 5, no. 1, p. 21, 2017.

[5] I. Imamah and A. Siddiqi, "Penerapan Teorema Bayes untuk Mendiagnosa Penyakit Telinga Hidung Tenggorokan (THT)," MATRIK J. Manajemen, Tek. Inform. dan Rekayasa Komput., vol. 18, no. 2, pp. 268-275, 2019.

[6] H. T. Sihotang, E. Panggabean, and H. Zebua, "Sistem Pakar Mendiagnosa Penyakit Herpes Zoster Dengan Menggunakan Metode Teorema Bayes," J. Inform. Pelita Nusant., vol. 3, no. 1, pp. 33-40, 2018.

[7] M. A. Fahmy, I. P. Ningrum, and J. Y. Sari, "Sistem pakar diagnosis penyakit hewan sapi dengan metode forward chaining," no. December, 2018.

[8] Suharjito, Diana, Yulyanto, and A. Nugroho, "Mobile Expert System Using Fuzzy Tsukamoto for Diagnosing Cattle Disease," Procedia Comput. Sci., vol. 116, no. Iccsci, pp. 2736, 2017.

[9] D. T. Yuwono, A. Fadlil, and Sunardi, "Penerapan Metode Forward Chaining dan Certainty Factor pada Sistem Pakar Diagnosa Hama Anggrek Coelogyne Pandurata," Kumpul. J. Ilmu Komput., vol. 04, no. 02, pp. 136-145, 2017.

[10] S. A. Nazari Somayeh, Fallah Mohammad, Kazemipoor Hamed, "A fuzzy inference- fuzzy analytic hierarchy processbased clinical decision support system for diagnosis of heart diseases," Expert Syst. Appl., vol. 95, pp. 261-271, 2018.

[11] J. Kajal, "Artificial Intelligence using forward chaining and backward chaining," Int. J. Innov. Res. Comput. Commun. Eng., vol. 6, no. 1, pp. 267-274, 2018.

[12] C. T. Pasaribu, N. Hidayat, and R. C. Wihandika, "Pemodelan Sistem Pakar Diagnosa Penyakit pada Tanaman Tembakau Virginia dengan Metode Dempster-Shafer," J. Pengemb. Teknol. Inf. dan Ilmu Komput., vol. 2, no. 5, pp. 2092-2094, 2018.

[13] A. Maseleno, A. Y. C. Tang, M. A. Mahmoud, M. Othman, and S. Saputra, "Fuzzy AHP Method to Determine Headache Types based on Symptoms Fuzzy AHP Método para determinar los tipos de cefalea según los síntomas," Invest. Clin., vol. 58, no. 2, pp. 235-245, 2017.

[14] R. Ramadhan, "Pemodelan Sistem Pakar Diagnosa Penyakit Tanaman Cabai Merah Dengan Metode Fuzzy-Ahp.," Repos. J. Mhs. PTIIK UB., vol. 6, no. 7, 2015.

[15] M. Maslim, "Sistem Pakar Pembelian Mobil Baru Menggunakan Logika Fuzzy.," in Digital Information \& System Conference. Computer Engineering Dept. Faculty of Engineering UK. Maranatha, 2013, pp. 108-113. 